\title{
Risk Toplumu Bağlamında Covid-19 Haberlerine Yönelik Bir İnceleme
}

\author{
DOI: 10.26466/opus.790554 \\ * \\ Mahmut Akgül* - Efe Numan Can ** \\ *Dr. Öğr. Üyesi, Erciyes Üniversitesi, Kayseri \\ E-Posta: mahmutakgl@gmail.com \\ ORCID: $\quad$ 0000-0003-1834-9588 \\ ** Arş. Gör., Aksaray Üniversitesi, Aksaray \\ E-Posta: efenumancan@gmail.com \\ ORCID: $\underline{0000-0002-4788-6553}$
}

\begin{abstract}
Öz
Yaşam varolduğundan beri insanoğlu farklı biçimlerde çeşitli risklerle karşılaşmışlardır. İlk çağlarda doğa şartlarına karşı savunmasız olan insanlar birlikte yaşamaya başlayarak ve çeşitli önlemler alarak bu risklere karşı durmaya çalışmıştır. Teknik anlamda yaşanan gelişmelerle birlikte farklı riskler ortaya çıkmış ve mücadele konusunda da yine bilime başvurulmuştur. Ilkel topluluklardan modern toplumlara kadar geçen dönemde büyük bilimsel gelişmeler yaşansa da gelinen noktada bu gelişmelerin sorunları da beraberinde getirdiği görülmektedir. Özellikle son iki yüzyılda yaşanan sanayi alanında gelişmeler ve büyük dünya savaşları teknolojik gelişimi hızlandırmış dünya hiç olmadığı kadar risklerle dolu bir yer olmuştur. Bu kapsamda Alman akademisyen Ulrich Beck içinde yaşanılan dönemi Risk Toplumu olarak adlandırmaktadır. Özellikle son dönemde tüm dünyada yaşanan Covid-19 salgını Beck'in kuramın ve endişelerini haklı çıkarır niteliktedir. Bu bağlamda çalışmada Beck'in Risk Toplumu bağlamında Covid-19 haberlerinin internet haber organlarında temsiline odaklanılmıştır. Çalışmada Hürriyet ve Sözcü gazetelerinin haber siteleri nitel ve nicel içerik analizi tekniği ile incelenmiştir. Elde edilen bulgular SPSS paket programı ve Maxqda nitel veri analiz programlarında analiz edilmiştir. Buna göre ilgili haber sitelerinde mayıs ayı içerisinde sunulan haberlerde kamuoyunu bilgilendirmeye yönelik haberlerin sıklı̆̆ı dikkat çekmektedir.
\end{abstract}

Anahtar Kelimeler: Risk Toplumu, Covid-19, Haber, Sözcü, Hürriyet 


\title{
A Review Of Covid-19 News In The Context Of The Risk Society
}

\begin{abstract}
Human beings have faced various risks in different forms since the existence of life. In the early ages, people who were vulnerable to natural conditions started to live together and tried to counter these risks by taking various measures. Along with the technical developments, different risks have emerged and science has been applied to combat. Although there have been great scientific developments in the period from primitive societies to modern societies, it is seen that these developments bring problems with them. Developments in the field of industry and great world wars, especially in the last two centuries, have accelerated technological development and the world has become a place full of risks than ever before. In this context, German academic Ulrich Beck calls the period in which we live in Risk Society. Especially the Covid-19 epidemic, which has been experienced all over the world recently, justifies Beck's theory and concerns. In this context, the study focused on the representation of Covid-19 news in internet news outlets in the context of Beck's Risk Society. In the study, news websites of Hürriyet and Sözcü newspapers were analyzed using qualitative and quantitative content analysis technique. The obtained findings were analyzed using SPSS package program and Maxqda qualitative data analysis programs. Accordingly, the frequency of news aimed at informing the public in the news presented on the relevant news sites in May draws attention.
\end{abstract}

Keywords: Risk Society, Covid-19, News, Sözcü, Hürriyet 


\section{Giriş}

Günümüz toplumu risklerle doludur. 11 Eylül saldırıları sadece ülkeleri ve büyük şirketleri değil sıradan vatandaşlarında terörizmin hedefinde olduğunu göstermiştir. Bununla beraber küresel ssınma, AIDS, HIV, nükleer savaş tehlikesi, salgın hastalıklar, büyük çaplı kazalar gibi her gün büyük risklerle karşı karşıya kalınmaktadır (Slatterry, 2014, s. 454). II. Dünya Savaşı sonrasında ABD ile SSCB arasında yaşanan ve "Soğuk Savaş" olarak adlandırılan dönem iki ülke arasındaki rekabetin bilimsel gelişmelere yansımasını beraberinde getirmiştir. Uzay hakkında yapılan çalışmalar, nükleer enerjinin yaygınlaşması, petrol bazlı yakıtların kullanımının artması insan hayatını kolaylaştırıı birçok fayda sağlarken; 1986 yılının Nisan ayında Çernobil Nükleer Santrali'nde yaşanan patlama içinde yaşadığımız toplumun barındırdığ riskleri tekrar hatırlatmıştır. Etkileri günümüzde bile hissedilen bu kazanın yarattığ 1 tedirginlik hissi 2011 yılında Fukuşima Nükleer Santralinde yaşanan sızıntıyla tekrar gündeme gelmiştir. Sadece nükleer felaketler değil insanlık tarihi boyunca yaşanan salgınlarda büyük kayıpların verilmesine yol açmıştır. Veba salgınları, kolera, tifüs, suçiçeği, kızamık, HIV, AIDS, Ebola vb birçok virüs kitlesel manada milyonlarca insanın canına mal olmuştur. Modernleşme sürecinin doğal sonuçları olarak yaşanan bilimsel gelişmeler farklı sektörleri de benzer şekilde etkilemiştir. Özellikle medya alanında yaşanan tartışmalar mahremiyet ve gözetim noktasında bireyin güvende olmadığı hissiyatına kapılmasına yol açmaktadır. Bu durum içinde yaşanılan çağın tedir-

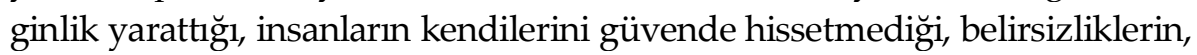
savaş tehlikelerinin, nükleer felaketlerin, yeni virüslerin ya da salgınların ortaya çlkma ihtimali olan bir toplum tasviri sunmaktadır.

2019'un Aralık ayında Çin'in Vuhan kentinde ortaya çıkan ve Covid-19 olarak adlandırılan salgın sosyal, siyasal, ekonomik ve kültürel tüm yaşam alanlarını etkilemiştir. Öyle ki eğitim kurumları, ticari kuruluşlar, kamu ya da özel sektörün büyük kısmı faaliyetlerini fiziki ortamlarda gerçekleştiremeyecek duruma gelmiştir. Dünyanın neredeyse tamamında görülen Covid-19 küresel bir salgın haline gelmiştir. Salgın nedeniyle her geçen gün binlerce yeni vaka sayısı açıklanmaktadır. Vaka sayılarına paralel olarak binlerce insan hayatını kaybetmiştir. 4 ay gibi kısa bir sürede tüm dünyaya yayılan virüs ekonomilerin gerilemesine ve ciddi toplumsal sorunlara yol açmıştır. Post- 
modern dünyanın küreselleşmeyle birlikte sınırları ortadan kaldırması, seyahat imkanlarının gelişmişliğiyle birlikte düşünüldüğünde virüsün yayılma hızının yüksek olması daha net anlaşılmaktadır. Bu süreç içerisinde insanlık kendini ve sevdiklerini riske atmamak adına mümkün olduğu kadar sokağa çıkmamaya, rutin işlerini dijital ortamlarda yapmaya çalışmaktadır. Ancak insanlığın büyük bir risk altında olduğu gerçektir.

Nitekim Alman Akademisyen Ulrich Beck'in "Risk Toplumu: Yeni Bir Moderniteye Doğru" adlı eseri Çernobil Felaketinin ardından yayınlanmış ve postmodern toplumu anlamak için bir perspektif geliştirilmiştir. Beck için post-modern toplumun tanımlayıcı özelliği risktir. İçinde yaşadığımız süreç risk toplumudur. Ulrich Beck riski modernleşmenin meydana getirdiği tehlikelerle sistemli bir ilişki içinde olmak olarak tanımlamaktadır. Beck bu bağlamda modern toplumu risk özelinde tanımlamakta ve risklerinde büyük oranda insanlığın kendi üretimi olan küresel olgulardan kaynaklandı̆̆ını ileri sürmektedir (Slatterry, 2014, s.454). Giddens (2010, s.159) risk toplumunda bireyin karşı karşıya kaldığı tehlikelere karşı çaresizleştiğinin altını çizmektedir.

Risk Toplumu ile ilgili dünyada ve Türkiye'de yapılmış farklı alanlardan pek çok çalışma mevcuttur. Bu çalışmalardan bazıları terörizm (Erendor, 2016; Üvez, 2014), modernleşme (Soydemir, 2011; Bakır ve Bahtiyar, 2013), güvenlik (Koçak ve Memiş, 2017; Özben, 2010; Çevik, 2014), belirsizlik (Esgin, 2013; Ertürk, 2018), doğal afetler (Yıldırım, 2008), din (Günerigök, 2017; Aslan, 2020), medya (Saf, 2017; Köse, 2007; Cottle, 1998; Kline, Stewart, ve Murphy, 2006; Bakir, 2010; Kitzinger, 1999; Chalaby ve Segell, 1999), kriz (Canpolat, 2012), korku (Korkmaz, 2019), küreselleşme (Yıldırım , 2000; Bayhan, 2011), gida (Lu ve Zhang, 2010), hukuk (Howell, 2012), sanat (Kleppe, 2017), teknoloji (Webster, 1999; Fitzgerald ve Rubin, 2010), çevre (Cohen, 1997) gibi alanlarda yapılmıştır.

Bu çalışmada ise Ulrich Beck' in Risk Toplumu adlı eserinden yola çıkarak Covid-19 salgınının internet haber organlarında sunumunu karma yöntemle incelenecektir. Bu kapsamda Covid-19 salgınının haber sitelerinde sunumunda kullanılan ifadeler ve tercih edilen kelimelerin neler olduğu temel araştırma sorusudur. Çalışma Risk Toplumu hakkında yazılan çok sayıda akademik ürünün yanında Covid-19 salgınına ilişkin haberlerin internet ha- 
ber organlarında 1 aylık süre zarfında çıkan haberlerin tamamına yönelik inceleme gerçekleştirilmesi nedeniyle özgünleşmektedir. Kullanılan verinin çokluğu düşünüldüğünde literature katkı sağlayacağı düşünülmektedir.

\section{Risk Kavramı ve Risk Toplumu}

Risk kavramı bir faaliyette bulunmanın sonucunda faaliyete gireni bekleyen tehlike ya da tehdittir. Faaliyete giren bu faaliyetin bir tehlike arz ettiğini ve neticesinde bir olumsuzlukla karşılaşabileceğini bilerek faaliyette bulunmaktadır. Risk kavramı deniz ticaretinde korsanların yağmalama tehlikelerine karşı geliştirilmiş bir kavramdır (Ertürk, 2018, s.281). Furedi'ye göre (2001, s.43) risk kavramı bir tehlike anında hasar alma, zarar görme, yaralanma veya ölümle sonuçlanabilecek olumsuzluklarla karşılaşma ihtimalini ifade etmektedir. Beck'e göre (2014, s.24) Kristof Kolomb gibi kaşiflerin yaşadığ1 dönemde risk kavramının bireysel olduğunu ve risk teriminin tüm insan yaşamına etki eden tehditleri değil cesaret ve macerayı çağrıştırdığını ifade etmektedir.

Risk sözcügünün kökeni İspanyolca ve Portekizcedir. “Bilinmeyen sulara yelken açmak" anlamında kullanılan risk fikri 16. ve 17. yüzyılda ortaya çımıştır. Daha sonra İngilizceye geçen risk öncelikle mekânsal bağlamda değerlendirilmiştir. Ardından yatırım yapanların arasında ve bankacılık sektöründe olası sonuçların hesaplanması bağlamında zaman düzlemine taşınmıştır. Daha sonraları ise belirsizlik ihtiva eden tüm durumlar için kullanılan ve kapsamı genişleyen bir kavram olmuştur (Giddens, 2000, s.36).

Sanayi öncesi toplumların yaşamlarında genellikle doğa kaynaklı ve insan faktörü dışında gelişen riskler ve tehlikeler bulunmaktaydı. Seller, veba, kuraklık bunlara örnek gösterilebilir. Sanayi toplumunda ise insanoğlu doğayla başa çıabilmek ve kontrolü ele almaya başlamaktadır. Selleri engellemek adına barajlar ve setler inşa ederek, salgın hastalıklardan korunmak için ilaçlar üretmek ve yiyeceği besinleri kendisi üreterek çeşitli adımlar atılmıştır. Ancak doğayla mücadele etmek adına girişimlerde bulunan insanoğlu bunları yaparken kendi ürünü olan tehlikeleri de beraberinde getirmeye başlamıştır. İnsan sağlığına yönelik bu tehditlere fabrikaların yol açtığı hava kirliliği örnek gösterilebilir (Slatterry, 2014, s.455). Beck'in Risk Toplumu teorisinde de görüldüğü üzere devletlerin ya da toplumların kendilerini geliş- 
tirme çabaları sonucu ortaya çıkan ekonomik ve teknolojik gelişim yeni risklerin üretilmesini beraberinde getirirken bu toplumlar ve devletleri de risk üreticisi konumuna taşımaktadır (Erendor, 2016, s.125).

Ulrich Beck "Risk Society: Towards a New Modernity" adlı eserinde 19. yüzyılda "ya - ya da" fikrinin hâkim olduğunu ve bu yüzyılda uzmanlık, tekdüzelik, ayrışma gibi kavramlar önem arz ederken; 20. yüzyılda ise "ve" fikrinin önemli olduğunu belirtmektedir. Yanyanalık, sentez, bulanıklık, çokluk kavramları bu hâkim düşüncenin ürünüdür. 21. yüzyılda ise geçerli olan felsefe yine "ve" olmakla birlikte işleyişin daha kaotik bir süreci işaret ettiği söylenebilir (Yalçınkaya ve Özsoy, 2003, s.5; Bayhan, 2002, s.188-189; Beck, 2005, s.9-11).

Beck'e göre zamanımızın anahtar kelimesi "Post" sözcügüüdür. Her şey "post"tur. Postmodernizm ile belirsizlikler artmıştır. Beck klasik sanayi toplumunda refah üretim mantığının risk üretim mantığına hâkim durumdayken günümüzde bu ilişkinin tersine döndüğü görüşündedir. Beck' göre modernleşme sürecinde üretici güçlerin gelişiminde yaşanan büyük ivme ile tehditler ve tehlikelerin potansiyeli daha önce eşi benzeri görülmemiş biçimde artmıştır (Beck, 2014, s.7-23).

Beck refah bölüşümünün yerini risk bölüşümüne bıraktığ 1 ikinci bir modernleşme çağında olduğumuzu savunmaktadır. Bilgi teknolojilerinde yaşanan gelişim ve sosyal devlet anlayışında yaşanan dönüşümle bu değişiklik meydana gelmiştir. Bu düşünceye göre sanayi toplumunu ortaya çıaran klasik modernleşmenin yerini Beck' in self-refleksif adını verdiği modernleşme almaktadır. Nasıl ki modernleşme geleneksel dünya görüşleri ve sınıf ayrıcalıklarını bozmuşsa klasik sanayi toplumunun bilim ve teknoloji üzerindeki etkisi de bozulmuştur. Modernleşmenin dönüşümsel hale gelmesi ilkeleri bakımından sorgulanmasına yol açmaktadır. (Timur, 2017, s.189).

Beck geç modernlikte üretilen risklerin (radyoaktivite, havada, suda ve gida maddelerinde bulunan zehirli maddeler ve bunların insan, hayvan ve bitkiler üzerindeki etkisi) servet mantığından farklı olduğunu savunmaktadır. Bu riskler gözle görülmemekte, çoğu zaman geri alınamaz hasarlara yol açmakta ve hakkında yapılan bilimsel ya da anti-bilimsel bilgiler dahilinde var olmaktadır. Dolayısıyla riskler bilgi dahilinde önemli veya önemsiz görülebilmekte, çok çarpıcı bir hal alabilmekte ya da tehlikesizmiş gibi gösterilebilmektedir. Bu bağlamda riskleri tanımlama konumunda olan bilimsel ve 
hukuki meslekler toplumsal ve siyasi konumları gereği kilit rolündedir (Beck, 2014, s.27).

Postmodern çağda insan doğanın kontrolünü ele almaya çalışmış ve böylelikle büyük bir yıkım riski ile karşı karşıya kalmıştır. Atomun parçalanması büyük bir enerji kaynağı olarak fayda sağlarken aynı zamanda çok güçlü kitle imha silahları elde edilmesine de yol açmıştır. Genetikle ilgili yapılan çalışmalar DNA'nın şifrelerinin açığa çıkarılmasını sağlayarak birçok hastalığın tedavisinde kullanılırken canlı klonlama imkanını da beraberinde getirmiştir. Petrol bazlı yakıtlar tüm dünyanın enerji ihtiyacına karşılık verirken diğer yandan küresel ısınma gibi sorunların ortaya çıkmasında başat faktör olmuştur. İnsanoğlu doğanın kontrolünü ele geçirmeye çalıştıkça sadece bulunduğu bölgenin değil tüm dünyanın daha büyük riskler altında kaldığı görülmektedir (Slatterry, 2014, s.455).

Beck risklerin paylaşımından bazı kesimlerin daha fazla etkilendiğini dolayısıyla toplumsal risk konumlarının ortaya çıktı̆̆ını ifade etmektedir. $\mathrm{Bu}$ risk konumları oluşsa da nihayetinde riski üreten ve onlardan kazanç sağlayanlarda bu risklere maruz kalmaktadırlar. Beck bu durumu "bumerang etkisi" olarak açıklamaktadır. Ekolojik yıkım ve radyoaktif maddelerin sızıntısı ülke sınırlarını tanımamaktadır. Zenginler ve güçlüler de sadece sağlık anlamında değil mülkiyet, meşruiyet ve kar anlamında da risk altındadır. Riskler farklı ülkeler arasında yeni eşitsizliklerin ortaya çıkmasına yol açmaktadır. Bir ormandaki bitkinin hayatı en nihayetinde uluslararası anlaşmaların yapılmasına neden olmaktadır. Bu kapsamda risk toplumu tüm dünyayı ilgilendirdiği için dünya risk toplumu olarak addedilmektedir (Beck, 2014, s.2728).

Beck risk durumlarının kazananlar açısından büyük çaplı kazanç kapıları olarak karşımıza çıktığını vurgulamaktadır. Kaybedenlerin yanısıra kazananlarında olduğu risk toplumunda güç dengelerine göre bu durum değişkenlik göstermektedir. Sanayi toplumu yarattı̆̆ riskler üzerinden ekonomik sömürü düzeni geliştirmiştir. Ancak Beck zenginliğe sahip olunsa da riskler karşısında ancak mağdur olunacağını belirtmektedir. Beck'e göre risk toplumu felaket toplumudur ve bu toplumda olağanüstü halin normalleşmesi tehlikesi vardır (2014, s.28-29). Risk toplumunun bilime yaklaşımı, bilimin egemenliğinin yerinden etmek adına bir mücadele değil aksine rasyonel aklın sorgulanmasına ve normatif ilkelerin tartışma konusu yapılmasına karşın 
bilimin sahip olduğu egemenliği korumasına yardımcı olmaktadır. Bu bağlamda risk toplumunda bilim risklerin üreticisi olduğu kadar aynı zamanda bu risklerin tanımlayıcısı ve çözüm kaynağıdır (Erendor, 2016, s. 189). Bu bağlamda bilimsel gelişmelerin, ilerlemenin kitle iletişim organlarında sunumu da büyük önem arz etmektedir. Kamuoyuna sağlıklı bilgi aktarmak ancak kitle iletişim araçları aracılığıyla mümkün olacağı düşünülmektedir. Ancak bu durum ütopik bir düşünce olarak algılanmaktadır. Nitekim medyanın sahiplik yapıları, siyasi otoritelerle ve çok uluslu şirketlerle olan ilişkileri ekonomi-politik açıdan eleştirilere yol açmaktadır.

İkinci Dünya Savaşı sırasında atom bombasının kullanılmasıyla bilimin gücü, kavranması, kontrol altına alınması gerektiği, bu kontrol süreciyle ilgili yurttaşların da katılımının sağlanması gibi konular gelişmiş ülkelerin gündemlerine taşınmıştır (Dursun, 2010, s.10). Dolayısıyla günümüzde yaşanan Covid-19 salgınının yarattığ belirsizlik ortamında yine bilimsel tavsiyeler ve çalışmalarla mücadele edildiği bir gerçektir. Kamuoyu Sağlık Bakanlığı tarafından "sosyal mesafe, evde kal, hayat eve sığar" gibi sloganlarla kitle iletişim araçları vasıtasıyla Covid-19 sürecinde bilgilendirilmeye çalışılmıştır. Bu kapsamda çalışmanın temel araştırma konusu olan Covid-19 salgınının haber sitelerinde sunumu açısından hareket edilerek Covid-19 haberleri incelemeye tabi tutulmuştur. Bu bilgiler ışığında Covid-19 salgınıla ilgili bazı bilgileri vermek yararlı olacaktır.

Koronavirüsler $(\mathrm{CoV})$, soğuk algınlığından Orta Doğu Solunum Sendromu (MERS-CoV) ve Şiddetli Akut Solunum Sendromu (SARS-CoV) gibi daha ciddi hastalıklara kadar çeşitli hastalıklara neden olan büyük bir virüs ailesidir (Sağlık Bakanlığı, 2020). 2019'un aralık ayının sonunda Çin' in Vuhan kentinden farklı bir tür virüse ait olduğu belirtilen zatürre vakaları bildirilmiştir. Vakaların ortaya çıktığı düşünülen Vuhan Deniz Ürünleri Pazarı tedbir amacıyla kapatılmıştır. 11 Ocak 2020'de Çin'de Covid-19'a bağlı ilk ölüm gerçekleşmiştir. Yeni bir koronavirüs olan virüs 12 Ocak 2020'de geçici olarak 2019-nCoV olarak tanımlanmıştır. DSÖ koronavirüslerin soğuk algınlığı gibi hafif hastalıklardan SARS ve MERS gibi ağır hastalıklara kadar farklı sorunlara yol açabildiğini belirtmiştir. Ancak eldeki bilgilere göre Çin'e yapılacak seyahatlere engel bir durumun olmadığı ifade edilmiştir. Çin'de 18 Ocak 2020 'de resmi makamlar tarafından yeni bir tip koronavirüs olduğu bilinmesine rağmen yeni yıl kutlamaları iptal edilmeyerek binlerce kişinin enfekte 
olmasına yol açılmıştır. 20 Ocak'ta insandan insana bulaştığı anlaşılan virüsün DSÖ tarafından Çin dışında insandan insana bulaş olmadığını açıklaması ise süreç içerisinde büyük bir hata olarak göze çarpmaktadır. 25 Ocak'ta Hong Kong'ta acil durum ilan edilip okullar kapatılırken Almanya'da ilk vaka ortaya çıkmıştır. 28 Ocak'ta Fransa, Brezilya ve Kanada'da vakalar görülmüştür. 30 Ocak'ta DSÖ küresel acil durum ilan ederek durumun ciddi olduğunu dünya kamuoyuna göstermiştir. 5 Şubat 2020 tarihinde DSÖ virüse karşı etkin bir tedavinin bulunmadığını ilan ederken bu yeni hastalığın COVID-19(Co: Corona, VI: Virüs, D: Disease, 19: İlk saptanan yıl olan 2019) olarak adlandırılacağını beyan etmiştir. Türkiye'de ilk vaka 10 Mart 2020 tarihinde görülürken 11 Mart'ta DSÖ tarafından Covid-19 salgını pandemi olarak ilan edilmiştir (YÖK, 2020).

Covid-19'un yayılmaya başlamasıyla dünya genelinde tüm odak noktaları bu yönde birleşmiştir. Salgınla ilgili tüm ülkelerde tedbirler alınmaya başlamış ve kitle iletişim araçları ile kamuoyu bilgilendirilmeye çalışılmıştır. Ancak bu durum gerçekleştirilirken elbette medyanın haberi sunma biçimi etkili olmuştur. Kimi ülkeler salgınla ilgili rahat bir tavır takınırken, kimi ülkelerde salgının yayılmaya başladığı anda teyakkuza geçmiştir. Bu kapsamda Türkiye salgının ulaşma zamanı dikkate alınacak olursa şanslı sayılabilecek ülkeler arasındadır. Çünkü salgının ortaya çıtığı Çin'e yakın ülkeler hazırlıksız yakalanırken Türkiye gibi uzak ülkeler salgınla ilgili hazırlıklarını yapma fırsatı bulmuşlardır. Kitle iletişim araçları da salgının ortaya çıktığı andan itibaren ilgilerini bu yöne çevirmiş̧ir. Türkiye'de gerek yazılı basında gerekse internet ortamında salgınla ilgili özel sayfalar oluşturmuşlardır. Salgınla ilgili haberler internet ortamında sürekli güncellenerek okuyucuyla buluşturulmuştur.

\section{Risk Toplumu ve Medya İlişkisi}

Teknolojik gelişim insan hayatını kolaylaştıran birçok özelliği barındırmasına rağmen beraberinde tehditleri ve tehlikeleri de getirmektedir. Nitekim yaşanan iki büyük dünya savaşı teknolojik gelişim olanaklarıyla kitlesel ölümlere yol açmıştır. Teknolojik gelişim sadece savaş endüstrisinde değil hayatın diğer pek çok alanına da doğrudan etki etmiştir. Özellikle kitle iletişim araçları açısından son yüzyılda yaşanan gelişmeler toplumların dönüşümlerinde başat faktörlerden biri olmuştur. Ancak kitle iletişim araçlarının yarattı̆̆ etkiler 
de tıpkı teknolojik gelişmelerin diğer alanlarda yaptığı gibi olumlu ve olumsuz olarak ayrılabilir. Temel görevleri bilgilendirmek, eğlendirmek olan kitle iletişim araçları kitleleri manipüle ederek tutum ve davranışların şekillenmesinde etkili olmaktadır. 20. yüzyılın başlarında en önemli bilgi kaynağı yazılı basın iken; I. Dünya Savaşı'nı takip eden dönemde radyo etkisini artırmıştır. Öyle ki kitle iletişim araçları üzerinden verilen haberler kitleler üzerinde önemli etkilere yol açtı̆̆ anlaşılmaktadır.

Kitle iletişim araçlarının kitleler üzerinde yarattığı etkiye verilebilecek en güzel örnek 1938 yılında yaşanan Marslıların dünyayı istila ettiğine ilişkin yaşanan kitlesel panik halidir. Orson Welles' in romanından uyarlanan “Dünyaların Savaşı" oyunu esnasında araya giren ve CBS'te haberleri sunan spiker Marslıların silahlarıyla dünyayı istila ettiklerini ve New York'a doğru harekete geçtiklerini aktarmıştır. Panik ifadesi barındıran ses tonuyla ve hergün haberleri sunan spikere duyulan güven ile radyonun ilgili dönemde popüler iletişim aracı olması nedeniyle yaklaşık 1 milyon insanın paniğe kapılarak evlerini terkettikleri, sokağa döküldükleri daha sonar yapılan araştırmalarla açığa çıkmıştır (Güngör, 2018, s.89-90).

Sonraki dönemlerde televizyonun toplumların hayatına girmesi ise çok daha büyük bir dönüşüm yaratmıştır. Televizyonun uzun süredir devam eden güçlü etkisine 20 yüzyılın sonu 21. Yüzyılın başı itibariyle bilgisayar ve internet alanında yaşanan gelişmelerde eklenmiştir. Bu kapsamda özelde kitle iletişim araçları genelde medya üzerinden veri bombardımanına tutulan toplumlar yanlış ve maksatlı bilgilerin kurbanı olmaktadırlar. Yaşanan dezenformasyon kitleleri belirsiz, dipsiz bir kuyunun içine çekmektedir. Neyin doğru neyin yanlış olduğunun belli olmadı yeni medya ortamı kitlelerin kendilerini tedirgin hissetmelerine yol açmaktadır.

Medya yaşanan gelişmeleri kimi zaman abartarak kimi zaman ise ajite ederek kitleler üzerinde manipülatif etkiler yaratmaktadır. Medyanın ve özelde kitle iletişim araçlarının sahiplik yapılarıyla ilgili eleştiriler uzun süredir tartışılmaktadır. Bu durum medyanın asli görevlerinden olan bilgilendirme ve eğlendirme için de geçerlidir. Ancak medya gerçekleri olduğu gibi değil eşik bekçilerinin bakış açılarından geçirerek kitlelere aktarır. Kitle iletişim araçlarından gelen haberler, bilgiler ekonomi-politik faktörler ışı̆̆ında değerlendirilerek anlamlandırılabilir. Bu bağlamda Covid-19 sürecinde de tüm dünyada medya organları tarafından bilgi bombardımanı başlamış, virüsün yayılmaya başladığı dönemde toplumlar gelen sarsıcı görüntüler ve 
bilgiler nedeniyle evlerine kapanmış, ölüm haberleri ülkeleri ekonomik ve sosyal tedbirler almaya itmiştir. Özellikle Çin'den gelen ilk görüntülerde yürürken düssen ölen insanlar yer almaktaydı. Dünya genelinde bu virüsün önceki salgınlar gibi bölgesel kalacağ 1 küresel anlamda büyük bir etki yaratmayacağı düşünülürken hızla sınırları aşması Avrupa'ya ve Amerikaya sıçraması durumun ciddiyetini kanıtlamıştır. Doğal afetler, nükleer tehditler, savaş, açlık gibi çeşitli risklerin kanıksandığı ortamda riskin yeni boyutu Covid19 salgını olmuştur. Kitle iletişim araçları da salgınla ilgili haberler için özel sayfalar oluşturmuşlar, televizyon ekranlarında ve internet sitelerinde günlük vaka, ölüm ve ağır hasta sayılarının yer aldığı bilgileri kamuoyuyla paylaşmışlardır. Medya bu haberleri paylaşırken sosyal yaşamın büyük risk altında olduğunu kitlelere aktarmış ve toplumsal bir panik hali başgöstermiştir. Dolayısıyla medyanın kullandığı kelimeler doğrudan risk olmasada dolaylı olarak yeni bir riskin etkisini anlatmaya yönelik olduğu söylenebilir.

\section{Covid-19 Salgını}

Covid-19 salgını küreselleşmenin etkisiyle sınırların olmadığı ve seyahatlerin, insan dolaşımının hızlı bir şekilde gerçekleştiği günümüze denk gelmesi tüm insanlığı tedirgin etmektedir. Tıpkı enformasyonun dolaşımının hızı gibi insan hareketliliği, seyahat teknolojilerinde kullanılan gelişmiş araçlar vb nedenlerden ötürü Covid-19 kısa bir sürede tüm dünyaya yayılmıştır. Covid-19 ile ilgili bilgilere geçmeden önce insanlığın yaşadığı büyük salgınlara bakmakta fayda vardır. İnsanoğlu tarihinde birçok salgınla mücadele etmiş ve bu salgınlarda kitlesel olarak çok büyük kayıplar vermiştir.

M.Ö. 165-180 yılları arasında ortaya çıan ve bir veba salgını olan Antoninus salgını 2 bin kişinin ölümüne yol açmıştır. 541 yılında seferden dönen askerlerin İstanbul'a gelirken beraberinde getirdiği Jüstinyen vebası ise dönemin İstanbul nüfusunun \% 40 azalmasına yol açmıştır. 1346-1353 yılları arasında görülen ve tarihin en büyük pandemilerinden olan Kara Veba nedeniyle 75-200 milyon arasında insanın yaşamını yitirdiği düşünülmektedir. Kara vebanın Avrupa Kıtasında yarattığı büyük yıkım neticesinde dinde reformun ve diğer alanlarda yenilikçi hareketlerin başladığı düşünülmektedir. 15. yüzyılda Amerikan yerlilerinin Avrupalılarda karşılaşması sonucunda suçiçeği nedeniyle nüfuslarının \% 90'1 yok olmuştur. 1520-1576 yılları ara- 
sında bugün Meksika adını verdiğimiz yerde yaşanan cocoliztli salgınları nedeniyle 15 milyona yakın insan hayatını kaybetmiş ve Maya uygarlığının sonunu hazırladığı görüşü hakimdir. İnsanlık tarihinde bilinen 7 büyük kolera salgını meydana gelmiş ancak bunlardan en önemlisi üçüncüsü olan 18521860 tarihleri arasında meydana gelen salgındır. Bu salgın nedeniyle sadece Rusya'da resmi rakamlara göre 1 milyon insan hayatını kaybetmiştir. Tüm dünyada hayatını kaybedenlerin sayısı tam olarak bilinememektedir. 1855 1859 arasında Çin ve Hindistan'da da 12 milyon kişinin ölümüne sebep olan üçüncü veba salgınının etkileri ise neredeyse bir asır sürmüştür. Birinci Dünya Savaşı sırasında yaşanan Tifüs salgını neticesinde sadece Sovyetler Birliği'nde 3 milyona yakın insan hayatını kaybederken dünya genelinde sayının tam olarak bilenemediği söylenebilir. 1918 yılında tarihin gördüğü en büyük salgınlardan biri olan İspanyol Gribi ortaya çıkmış ve 75 ila 100 milyon insanın hayatını kaybetmesine yol açmıştır. 1957 yılında Çin'de ortaya çıkan Asya Gribi ise 4 milyona yakın insanın canına mal oldu. 20. Yüzyılın ortalarında Kongo' da ortaya çıkan HIV virüsü 30 milyondan fazla insanın hayatını kaybetmesine yol açmıştır (Aktan, 2020). Günümüzde hala tam olarak aşısı olmamakla birlikte HIV, AIDS nedenlerden binlerce insan hayatını kaybetmektedir. Bu hastalıkların henüz çözümü bulunamamışken 2019'un aralık ayında Çin'de ortaya çıkan Covid-19 benzeri görülmemiş bir risk ortamı oluşturmuştur.

Covid-19'un ortaya çıktığı ve hızla yayıldığg andan itibaren sosyal, siyasal ekonomik tüm alanlar olumsuz etkilenmiş dünya ekonomisi ciddi bir resesyon tehlikesi ile karşı karşıya kalmıştır. Bu kapsamda dünya genelinde bilim insanları Covid-19 salgını ve etkilerine yönelik araştırmalara ağırlık vermişlerdir. DSÖ'nün sitesinde yer alan salgınla ilgili bazı araştırmalar şu şekilde$\operatorname{dir}$ (WHO, 2020; Acar, 2020, s.9-10):

Mahase'in (2020) yaptığı çalışmalara göre maske ve solunum cihazı gibi koruyucu ve tedavi amaçlı kullanılan ekipmanlara olan talebin yüz kat arttığını aynı şekilde bu ekipmanların fiyatlarında ise \% 20'lik bir artışın söz konusu olduğunu belirtmektedir. Columbus, Brust ve Arrogila (2020) tarafından yapılan araştırmalarda ise 11 Şubat 2020 tarihine kadar virüsün dünya üzerinde yarattığı küresel tehditlerden ve yayılma alanlarından bahsedilmektedir. Ahmad, Khan, Khan ve Hui (2020) tarafından yapılan araştırmada ise koronavirüsle ilgili istatistiki veriler paylaşılarak Pakistan ve Çin arasın- 
daki mesafenin yakın olması, ticari ilişkiler gibi nedenlerle Pakistan'ın yüksek risk altında olduğu belirtilmektedir. Chen, Yang, Yang, Wang ve Bärnighausen (2020) tarafından yapılan çalışmada ise Çin' in yeni yıl kutlamaları sırasında oluşan büyük nüfus hareketi ve önlem alınmaması nedeniyle oluşan kaygıdan bahsedilirken, Covid-19 için alınması gereken önlemlere de yer verilmiştir. Rodriguez-Morales vd. (2020) tarafından yapılan çalışmada ise Brezilya'nın tarihsel süreçte bir çok salgınla uğraşmak zorunda kaldığı, Brezilya'da ilk koronavirüs vakası onaylandıktan sonra da toplam nüfusu 640 milyonu bulan Latin Amerika ülkelerinin risk altında olduğuna dikkat çekilmektedir. Ayittey, Ayittey, Chiwero, Kamasah ve Dzuvor (2020) tarafından Covid-19'un yaratacağı ekonomik sıkıntılar üzerine yapılan çalışmada Çin ekonomisinin yılın ilk çeyreğinde yaklaşık 62 milyar dolarlık bir kayıp yaşayacağ 1 düşünülürken dünya genelinde ise ilk çeyrekte 280 milyar doları aşan bir zararın ortaya çıktığı tahmin edilmektedir. Quilty, Clifford, CMMID nCoV Working Group, Flasche ve Eggo (2020) tarafından havaalanlarında termal kameraların virüs bulaşan insanları tespit etme noktasındaki etkinliğinin araştırıldığı çalışmada ise enfekte olan yolcuların yarısına yakınının termal kameralar aracılığıyla tespit edilemeyeceği sonucuna varılmıştır. Chiodini (2020) yaptığı çalışmada Dünya Sağlık Örgütü'nün virüsle ilgili yaptığ1 tanımlamalara, korunma yollarına değinmiş ve küresel çapta yapılacak yardımlaşmanın, işbirliğinin önemini vurgulamıştır. Bogoch vd, (2020) tarafından yapılan çalışmada virüsün etki alanının genişlemesi ve oluşabilecek muhtemel sorunlar değerlendirilmektedir. Du vd, (2020) tarafından yapılan çalışmada ise Vuhan'da ortaya çıkan koronavirüsün Çin'de bulunan tüm şehirlere yayılması tahmin edilmektedir. Wilson ve Chen (2020) tarafından yapılan çalışmada ise Çin'in Vuhan kentinden dünyanın farklı yerlerine yapılan seyahatlerin virüsün yayılmasına olan etkilerinden bahsedilmiştir. Acar' göre (2020, s.11) bu çalışmalardan anlaşılmaktadır ki özellikle turizm alanında yaşanacak hareketlerin küresel çapta yayılması adına büyük bir tehdit oluşturduğu anlaşılmaktadır. Ayrıca sağlık ekipmanlarına yönelik olarak artan talep ve ihtiyaca paralel olarak bu ekipmanların fiyatlarında da ciddi artışlar meydana geleceği öngörülmektedir. 


\section{Yöntem}

Çalışma kapsamında Covid-19 salgınına yönelik haberlerin risk toplumu bağlamında internet haber organlarında sunumu incelenmektedir. Çalışmada karma yöntem tercih edilmiştir. Bu bağlamda nicel ve nitel araştırma yöntemlerinden içerik çözümlemesine başvurulmuştur. İçerik çözümlemesi metinler ya da diğer anlamlı içeriklerden geçerli çıkarımlar yapılmasına olanak sağlayan ve kullanıldıkları bağlamda değerlendirilen bir teknik olarak tanımlanmaktadır (Krippendorff, 2004, s.18). Yıldırım ve Şimşek'e göre (2008, s.227) ise verilerin birbirine benzediği durumlarda belirli temalar aracılığıyla gruplar haline getirmek ve bunları okuyucunun daha rahat anlayabileceği bir formata dönüştürmektir. Elo ve Kyngash (2008, s.113) bir konuda daha önceden araştırma yapılmamış ve var olan bilgilerin dağınık olduğu olgular için nitel içerik çözümlemesini önerirken mevcut bir teoriyi farklı bir olgu için denemek ve bu kategorileri zaman olarak farklı dilimlerde tekrar test etmek için nicel içerik çözümlemesini önermektedir.

Salgınla ilgili 1 Mayıs 2020-31 Mayıs 2020 tarihleri arasındaki haber sitelerinde yer alan haberlerin çözümlemesi gerçekleştirilmiştir. Mayıs ayının tercih edilme sebebi Türkiye'de ilk vakanın 11 Mart 2020'de görüldügü düşünülecek olursa mart ve nisan ayları tedbirlerin en üst seviyeye çıkarıldı ̆̆ı aylardır. Dolayısıyla bu tedbirlerin etkileri ve haberlere yansımaları mayıs ayında olacağı düşünülerek tercih edilmiştir. Ancak internet ortamında çok sayıda haber sitesinin mevcut olması ve Covid-19'la ilgili yapılan haberlerin sayısının çokluğu göz önüne alındığında tamamının incelenmesi zaman s1nırlılığı nedeniyle mümkün gözükmemektedir. Türkiye'de en çok tıklanan, sahiplik yapısının birbirinden farklı ve Covid-19 ile ilgili geçmiş haberlere ulaşma imkânı verme parametreleri göz önüne alınarak www.hurriyet.com.tr ve www.sozcu.com.tr siteleri nicel ve nitel içerik çözümlemesi tekniğiyle analiz edilmiştir. Elde edilen veriler SPSS 25.0 paket programı ve Maxqda nitel veri analiz programlarıyla analiz edilerek yorumlanmıştır.

\section{Bulgular ve Yorum}

Hürriyet ve Sözcü gazetelerinin internet sitelerinde 1 Mayıs 2020 - 31 Mayıs 2020 tarihleri arasında yayınlanan haberler nicel ve nitel içerik analizi yöntemi ile incelenmiş ve bulgular tablolar halinde sunulmuştur. 
Tablo 1.Hürriyet'te Yer Alan Haberlerin Tarihe Göre Değerlendirilmesi

\begin{tabular}{lll}
\hline Hafta & Frekans & Yüzde \\
\hline 2. Hafta & 585 & 26,4 \\
\hline 3. Hafta & 574 & 25,9 \\
\hline 1. Hafta & 532 & 24 \\
\hline 4. Hafta & 522 & 23,6 \\
\hline Toplam & 2213 & 100,0 \\
\hline
\end{tabular}

Hürriyet gazetesinin bir aylık süre içerisinde internet sitesinden yayınladığ ve Covid-19 anahtar kelimesi kullanılarak çekilen haberlerin haftalık bazda bilgileri Tablo 1'de gösterilmektedir. Tablo 1 incelendiğinde Hürriyet'in Covid-19 bağlantılı haberleri dengeli bir şekilde paylaştığı anlaşılmaktadır. Covid-19 bağlantılı toplam 2213 haberin paylaşıldığı bir aylık dönemde en fazla haber ikinci haftada paylaşılmıştır. 585 haberin paylaşıldığı ikinci haftayı 574 haberle üçüncü hafta takip etmektedir. 532 haberin paylaşıldığ1 birinci hafta üçüncü sırada yer alırken; son sırada ise 522 haberle dördüncü hafta yer almaktadır. Haberlerin dengeli paylaşımı Covid-19'un sürekli gündemde kaldığını kanıtlar niteliktedir.

Tablo 2.Hürriyet'te Yer Alan Haberlerin Kategorilendirilmesi

\begin{tabular}{lll}
\hline Kategori & Frekans & Yüzde \\
\hline Spor & 519 & 23,5 \\
\hline Dünya & 496 & 22,4 \\
\hline Ekonomi & 447 & 20,2 \\
\hline Gündem & 346 & 15,6 \\
\hline Avrupa & 155 & 7 \\
\hline Teknoloji & 115 & 5,2 \\
\hline Diğer & 72 & 3,3 \\
\hline Seyahat & 37 & 1,7 \\
\hline Eğitim & 21 & 0,9 \\
\hline Sağllk & 5 & 0,2 \\
\hline Toplam & 2213 & 100,0 \\
\hline
\end{tabular}

Hürriyet' in internet sitesinden paylaşılan Covid-19 ile ilgili haberler sitenin kendi kategorilerine göre Tablo 2' de sunulmuştur. Buna göre toplam 2213 Covid-19 bağlantılı haberden \%23,5'i "Spor" kategorisinde yer almaktadır. Covid-19 sürecinde tüm sektörlerde olduğu gibi spor endüstrisinin de en fazla etkilenen alanlardan biri olması ve uluslar/uluslararası müsabakaların ertelenmek zorunda kalınması bu sonucun ortaya çımasında etkili olduğu söylenebilir. Spor kategorisini 496 haber ve \% 22,4'lük oranla “Dünya” kate- 
gorisi izlemektedir. Covid-19'un küresel bir salgın olması bu kategoride paylaşılan haberlerin sayısının fazla olmasını beraberinde getirmiştir. Üçüncü sırada ise 447 haber ile "Ekonomi" kategorisi yer almaktadır. Covid-19'un y1kıcı etkilerinin en fazla görüldüğü alanlardan biri de ekonomidir. Tüm dünyada işletmelerin, kurumların ve kuruluşların karantina tedbirleri nedeniyle kapanması ekonomik yapılar üzerinde olumsuz etkiler yaratmıştır. Ekonomi kategorisini sırasıyla "Gündem (346), Avrupa (155), Teknoloji (115), Diğer (72), Seyahat (37), Eğitim (21) ve Sağlık (5)" kategorileri izlemektedir. Burada altı çizilmesi gereken nokta "Sağlık" kategorisinde görünen düşük haber sayısıdır. Covid-19 bir salgın ve pandemi olmasına rağmen "Sağlık" kategorisinde bu kadar haber olmasının nedeni pandeminin tüm yaşam alanlarına sirayet etmesindendir. Öyle ki Covid-19, Koronavirüs, Corona, Kovid gibi ifadeler olmadan neredeyse hiçbir haber yazılamamaktadır. Bu nedenle Covid-19 neredeyse tüm haberlerde geçmekte ve etkilediği alana göre kategorilendirilmektedir. Sağlık kategorisinde görülen 5 haber yanıltıcı olmamalıdır çünkü yapılan haberlerin çoğu bir şekilde Covid-19 ile bağlantılıdır.

Tablo 3.Hürriyet'te Yer Alan Haberlerin Kodlanması

\begin{tabular}{lll}
\hline Kodlar & Frekans & Yüzde \\
\hline Nötr & 589 & 26,6 \\
\hline Bilgilendirme & 525 & 23,7 \\
\hline İstatistik & 317 & 14,3 \\
\hline Tedbir & 267 & 12,1 \\
\hline Mücadele & 231 & 10,4 \\
\hline Destek & 143 & 6,5 \\
\hline Olumsuzluk & 141 & 6,4 \\
\hline Toplam & 2213 & 100,0 \\
\hline
\end{tabular}

Tablo 3 Hürriyet' in internet sitesinde mayıs ayında yayınlanan Covid-19 haberlerinin kodlanmasını göstermektedir. Toplam 2213 haberin paylaşıldığ 1 bir aylık süre zarfında 589 haberin içeriğinde Covid-19'a atıf bulunmasına rağmen mevcut durumun Covid-19'la bir ilgisi olmadığ için "Nötr" koduyla belirtilmiştir. Bir başka ifadeyle 2213 haberin 589'u içeriğinde Covid-19 ifadesini barındırmasına rağmen Covid-19'la ilgili haberler değildir. Nötr kategorisinde dışında 525 haber "Bilgilendirme" kategorisinde değerlendirilmiştir. $\%$ 23,7'lik bir orana karşılık gelen 525 haber Covid-19'la bağlantılı olarak bilgilendirici içeriklere sahiptir. Üçüncü sırada ise \% 14,3'lük oran ve 317 haber ile "İstatistik" kategorisi yer almaktadır. Covid-19'un dünya genelinde 185 ülkeye yayılması, günlük vaka ve ölüm oranlarının istatistiki veriler eşliğinde 
paylaşılmasını beraberinde getirmiştir. İstatistik kategorisini \% 12,1'lik oran ve 267 haber ile "Tedbir" kategorisi takip etmektedir. Salgınla ilgili alınan ulusal ve uluslararası önlemler bu kategori altında değerlendirilmiştir. "Mücadele" kategorisi ise 231 haberle beşinci sırada yer almaktadır. Covid-19'a yönelik tedavi gelişmeleri, aşı çalışmaları bu kategori içerisinde kodlanmıştır. Salgınla ilgili maddi ya da manevi destek haberleri "Destek" kategorisinde kendine yer bulmuştur. Bu kategoride toplam 143 haber yer almaktadır. Salginın olumsuz etkilerine yönelik haberler ise "Olumsuzluk" kategorisinde 141 haberle kodlanmıştır. Aslında salgının çok sayıda olumsuz etkisi olmasina rağmen sadece 141 haberin "Olumsuzluk" kategorisinde yer bulması ilginçtir. Bu durumun ortaya çıkmasında etkili olan faktör istatistik kodundan kaynaklanmaktadır. İstatistiki veriler olarak paylaşılan vaka sayıları ve ölüm oranları aslında olumsuzluk olarak değerlendirilebilir ancak dünya genelinde bu konuda haberler sunulurken sistematik bir biçimde ve tablolaştırılarak paylaşılmaktadır. Bu sebeple çalışmada "İstatistik" olarak ayrı bir kodlama yapılmasına gerek duyulmuştur.

Tablo 4.Sözcü'de Yer Alan Haberlerin Tarihe Göre Değerlendirilmesi

\begin{tabular}{lll}
\hline Hafta & Frekans & Yüzde \\
\hline 1. Hafta & 810 & 28 \\
\hline 2. Hafta & 721 & 24,9 \\
\hline 4. Hafta & 687 & 23,7 \\
\hline 3. Hafta & 678 & 23,4 \\
\hline Toplam & 2896 & 100,0 \\
\hline
\end{tabular}

Sözcü gazetesinin internet sitesinde yer alan Covid-19 ile ilgili mayıs ayı içerisinde paylaşılan haberler tarandığında toplam 2896 haberin paylaşıldı ̆̆ 1 anlaşılmaktadır. 2896 haberin mayıs ayında haftalara göre yayınlanma sıklığı Tablo 4'te gösterilmektedir. En fazla haber 810 ile birinci haftada yayınlanırken; en az haber 678 ile üçüncü haftada yayınlanmıştır. Sözcü'nün paylaştı̆̆1 haberlerin de Hürriyet gibi dengeli dağıldığını söylemek yanlış olmayacaktır. Sadece ilk haftada paylaşılan haberler diğer haftalara göre \% 4-5 oranında fazlalık göstermektedir.

Tablo 5.Sözcü'de Yer Alan Haberlerin Kategorilendirilmesi

\begin{tabular}{lll}
\hline Kategori & Frekans & Yüzde \\
\hline Gündem & 1183 & 40,8 \\
\hline Dünya & 632 & 21,8 \\
\hline Ekonomi & 478 & 16,5 \\
\hline Diğer & 309 & 10,7
\end{tabular}




\begin{tabular}{lll} 
Sağlik & 166 & 5,7 \\
\hline Eğitim & 95 & 3,3 \\
\hline Seyahat & 29 & 1 \\
\hline Teknoloji & 3 & 0,1 \\
\hline Spor & 1 & 0 \\
\hline Toplam & 2896 & 100,0 \\
\hline
\end{tabular}

Sözcü gazetesinin internet sitesinde yer alan Covid-19 bağlantılı haberlerin ilgili site tarafından kategorilendirilmesi Tablo 5 'te gösterilmektedir. Tablo 5'e göre Sözcü'nün mayıs ayında paylaştığı haberlerin toplam içerisinde \% 40,8'lik orana tekabül eden 1183'ü “Gündem” kategorisinde yer almaktadır. Gündem kategorisini 632 haber ile "Dünya" kategorisi izlemektedir. Sözcü'nün internet sitesi Hürriyet' in aksine Avrupa-Dünya ayrımına gitmeden tek kategoride toplamıştır. Üçüncü sırada "Ekonomi" kategorisi 478 haber ile yer almaktadır. Ekonomi kategorisini 309 haber ile "Diğer" izlemektedir. Diğer kategorisi içerisinde magazin, kültür-sanat ve yaşam alanında haberler yer almaktadır. Bu haberler "Diğer" kategorisinde birleştirilmiştir. "Sağlık" kategorisinde ise \% 5,7'lik oran ve 166 haber paylaşılmıştır. Hürriyet'ten farklı olarak "Sağlık" kategorisinde paylaşılan haber sayısının fazla olduğu görülmektedir. "Sağlık" kategorisini sırasıyla "Eğitim (95), Seyahat (29), Teknoloji (3) ve Spor (1)" kategorileri izlemektedir. Sözcü'de yer alan haberlerde sadece 1 adet "Spor" kategorisinde haber olması ve "Teknoloji" kategorisinde de oldukça az haber olması dikkat çekicidir.

Tablo 6.Sözcü'de Yer Alan Haberlerin Kodlanması

\begin{tabular}{lll}
\hline Kodlar & Frekans & Yüzde \\
\hline Bilgilendirme & 826 & 28,5 \\
\hline Tedbir & 478 & 16,5 \\
\hline Nötr & 464 & 16 \\
\hline Mücadele & 318 & 11 \\
\hline Olumsuzluk & 310 & 10,7 \\
\hline Destek & 274 & 9,5 \\
\hline İstatistik & 226 & 7,8 \\
\hline Total & 2896 & 100,0 \\
\hline
\end{tabular}

Sözcü'nün internet sitesinde yer alan mayıs ayı içerisindeki Covid-19 bağlantılı 2896 haber Tablo 6'da kodlanarak gösterilmektedir. Buna göre en fazla haber "Bilgilendirme" koduna dahil edilmiştir. Dünyanın ilk defa bu ölçekte ve böylesine büyük bir küresel salgınla karşılaşması bilgilendirici içeriklerle 
yazılan haberlere de yansımıştır. İkinci sırada \% 16,5'lik oran ve 478 haber ile Tedbir kodu yer almaktadır. Covid-19'a yönelik alınan önlemler 478 haberde kendine yer bulmuştur. Covid-19 ifadesi geçmesine rağmen içeriğin ilgisiz olduğu 464 haber ise "Nötr" başlığında üçüncü sırada yer almaktadır. Bu haberlerde genellikle Covid-19 ifadesi içerikle bağımsız olarak kullanılmıştır. Yine aşı çalışmaları ve tedaviye yönelik geliştirilen ilaçlarla ilgili haberler "Mücadele" başlı̆̆ı altında 318 haberle gösterilmiştir. Salgının olumsuz etkilerine yönelik içeriğin paylaşıldığı haberler, özellikle ekonomi, turizm gibi sektörlere yönelik olumsuz etkiler bu kod altında değerlendirilmiştir. Salginla ilgili ulusal-uluslararası yardım hareketleri, maddi-manevi destek çabalarının yer aldığı haberler \% 9,5'lik oran ve 274 haber ile "Destek" koduyla gösterilmektedir. Sözcü'de yer alan 2896 haberin 226 tanesi istatistiki verilerle ilgilidir. Günlük vaka ve ölüm oranları, iyileşen hasta sayısı bu kodlamayla tablonun son sirasinda yer almaktadır.

Tablo 7.Hürriyet ve Sözcü'de Yer Alan Haberlerde Geçen Önemli Kelimelerin Frekans Analizi

\begin{tabular}{|c|c|c|c|c|c|c|}
\hline \multicolumn{4}{|c|}{ Hürriyet } & \multicolumn{3}{|c|}{ Sözcü } \\
\hline Sira & Sözcük & Frekans & Toplam & Sözcük & Frekans & Toplam \\
\hline 1 & Kovid & 4995 & 0,78 & Corona & 11253 & 1,16 \\
\hline 2 & Virüs & 4231 & 0,66 & Virüs & 7531 & 0,78 \\
\hline 3 & Salgın & 3940 & 0,61 & Salgın & 3959 & 0,41 \\
\hline 4 & Korona & 3660 & 0,57 & Maske & 2721 & 0,28 \\
\hline 5 & Corona & 1353 & 0,21 & Mesafe & 1350 & 0,14 \\
\hline 6 & Tedbir & 1138 & 0,18 & Tedbir & 1348 & 0,14 \\
\hline 7 & Maske & 1056 & 0,16 & Önlem & 1245 & 0,13 \\
\hline 8 & Önlem & 846 & 0,13 & Karantina & 868 & 0,09 \\
\hline 9 & Mesafe & 735 & 0,11 & Pandemi & 740 & 0,08 \\
\hline 10 & Risk & 396 & 0,06 & Risk & 662 & 0,07 \\
\hline 11 & Pandemi & 378 & 0,06 & Korona & 396 & 0,04 \\
\hline 12 & Karantina & 373 & 0,06 & Hijyen & 331 & 0,03 \\
\hline \multirow[t]{2}{*}{13} & Hijyen & 211 & 0,03 & Kovid & 20 & 0 \\
\hline & Toplam & 23312 & 3,62 & Toplam & 32424 & 3,35 \\
\hline \multicolumn{4}{|c|}{ Tüm haberlerde kullanılan kelime sayısı: 641,641} & \multicolumn{3}{|c|}{ Tüm haberlerde kullanılan kelime sayısı: 965,256} \\
\hline
\end{tabular}

Hürriyet ve Sözcü gazetelerinin internet sitelerinde mayıs ayı içinde yayınlanan Covid-19 bağlantılı haberlerde geçen önemli kelimeler Tablo 7'de gösterilmektedir. Buna göre www.hurriyet.com.tr'de bulunan 2213 haberde geçen 641,641 kelimenin 23312'si Covid-19 ile bağlantılıyken www.sozcu.com.tr'de bulunan 2896 haberde geçen 965,256 kelimenin 32424'ü Covid-19 ile bağlantılı kelimelerden oluşmaktadır. Bu bağlamda 
Hürriyet'in paylaşttğı haberlerde "Kovid" kelimesi 4995, “Virüs" 4231, “Salgin" 3940, “Korona" 3660 ve "Corona” 1353 defa kullanıldığı anlaşılmaktadır. Covid-19 ile ilgili "Pandemi, Karantina ve Hijyen" ise en az kullanılan kelimeler olmuştur. Hürriyet'in haberlerinde büyük oranda Kovid ve Korona ifadeleri tercih edilmiştir. Başka bir deyiş̧ ile virüsün_Türkçe adı daha fazla kullanılmıştır. Sözcü'nün paylaştığı haberlerde ise en fazla kullanılan sözcükler “Corona" 11253, “Virüs" 7531, “Salgin” 3959, “Maske" 2721 ve “Mesafe" 1350 olmuştur. Sözcü' nün en az kullandığı kelimeler ise "Korona, Hijyen ve Kovid" dir. Sözcü haberlerinde büyük oranda Corona sözcügünü tercih etmiştir. Diğer bir ifade ile virüsün uluslararası alanda yaygın kullanımı tercih edilmiştir. Her iki sitede de salgınla ilgili “Maske, Mesafe, Salgın, Karantina, Önlem, Tedbir" gibi Covid-19'la tüm insanlığın yaşamına giren ifadelere başvurulmuştur.

Tablo 8.Hürriyet ve Sözcü'nün Kullandığı Haber Kaynakları

\begin{tabular}{llll}
\hline Hürriyet & & Sözcü & \\
\hline Haber Kaynağı & Frekans & Haber Kaynağı & Frekans \\
\hline AA & 1738 & AA & 2 \\
\hline DHA & 157 & DHA & 608 \\
\hline REUTERS & 19 & REUTERS & 164 \\
\hline BBC & 13 & BBC & 73 \\
\hline CNN & 10 & CNN & 53 \\
\hline Toplam & 1937 & Toplam & 900 \\
\hline 2213 & & 2896 & \\
\hline
\end{tabular}

Hürriyet ve Sözcü'nün kullandığı haber kaynaklarına bakıldığında ise durum Tablo 8'de ortaya konulmuştur. Buna göre Hürriyet mayıs ayı içerisinde Covid-19'la ilgili yaptı̆g haberlerin 1937'sinde haber kaynaklarını tercih etmiştir. Buna karşın Sözcü'nün aynı dönemde yaptığı 2896 Covid-19 bağlantılı haberin 900'ünde haber kaynaklarını tercih ettiği anlaşılmaktadır. Başka bir ifade ile Hürriyet Sözcü'ye göre haber kaynaklarına daha fazla başvurmuştur denilebilir. Hürriyet'in en fazla kullandığı haber kaynağı Anadolu Ajansı iken; Sözcü'nün en fazla kullandığı haber ajansı Demirören Haber Ajansı olmuştur. Sözcü'nün Hürriyet'e göre yabancı haber ajanslarından daha fazla yararlandığı Tablo 8'de görülmektedir.

\section{Kelime Analizi}

Kelime bulutu analizinde Maxqda nitel veri analizi programindan yararlanılmıştır. Çelik'e göre (2020, s. 136) kelime bulutlarında en sık kullanılan 
ifadeler büyük görsellerle gösterilirken kullanım sıklığı azaldıkça görsellerin de boyutları küçülmektedir.

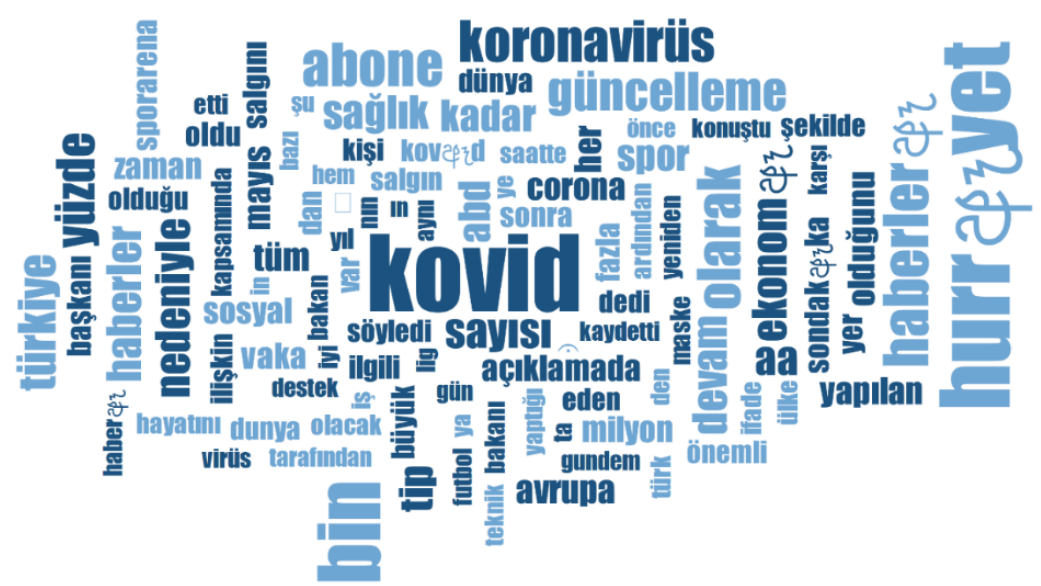

\section{Şekil 1.Hürriyet'in Kelime Bulutu}

Hürriyet'te yer alan haberlerde geçen kelimelere ait kelime bulutu Şekil 1'de gösterilmektedir. Kelime bulutu analiz edilirken bağlaç ve edatlar gibi konuyla ilgisiz ifadeler dışlanarak hareket edilmiştir. Tablo 7'yi doğrular nitelikte kelime bulutunun merkezinde "Kovid" ifadesinin yer aldığı görülmektedir. Yine kelime bulutuna göre salginla ilgili olarak "koronavirüs, corona, sayısı, güncelleme, sağlık, kovid, yüzde" gibi ifadelere yer verildiği ortaya çıkmaktadır.

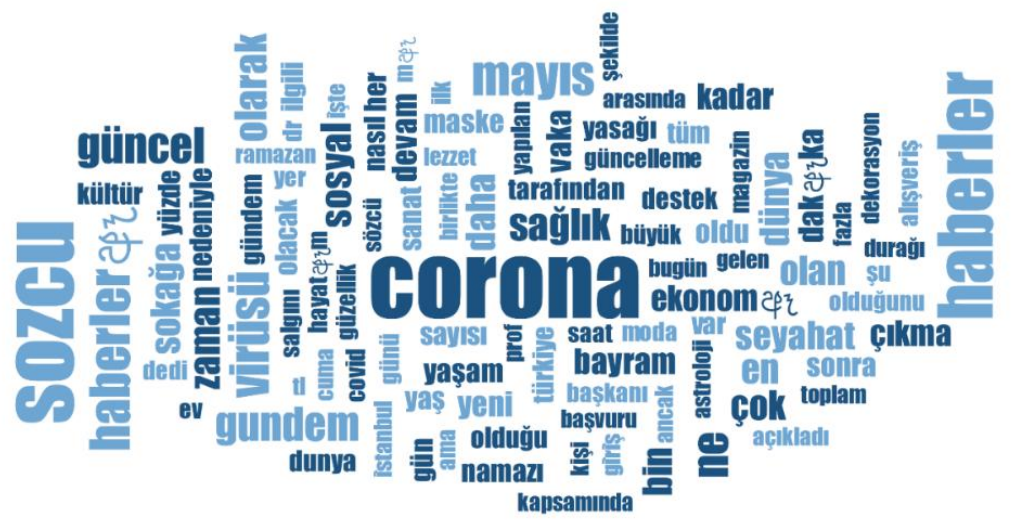

Şekil 2.Sözcü'nün Kelime Bulutu 
Sözcü'nün haberlerinde yer alan kelimelere bakıldığı zaman yine en fazla kullanilan en büyük boyutta ve merkez de yer almıştır. Sözcü'nün haberlerinde en fazla yer verdiği kelime Tablo 7'ye göre "corona" olduğu için kelime bulutu da bu durumu doğrulamaktadır. Salgınla ilgili olarak yine Sözcü'ye ait kelime bulutu incelendiğinde "sağlık, virüsü, sosyal, sokağa, yüzde, güncel" gibi ifadelerin kullanıldığı anlaşılmaktadır.

\section{Sonuç}

İçinde yaşadığımız çağa kimi düşünürler bilgi çağı, enformasyon çağı, postmodern dönem, tedirginlik çağı derken çalışmaya konu olan Ulrich Beck ise "Risk Toplumu" kavramını tercih etmiştir. Çernobil felaketinin ardından yayımlanan eseriyle dönemin koşulları içerisinde o döneme ve geleceğe dair bir değerlendirme sunan Beck, günümüz toplumunun risk toplumu olduğunu ve insanların sürekli risk altında olduğunun altını çizmektedir. Gerçekten de yaşanan bilimsel ve teknik gelişmelere bakıldığında bir yanda sağlık, tıp, genetik gibi alanlarda yaşanan ilerleme insan sağlığına ve ömrüne pozitif yönde katkı yaparken, diğer yandan savunma sanayi, petro-kimya, nükleer enerji alanlarında yaşanan gelişmelerin yıkıcı etkileri dikkat çekmektedir. 20. Yüzyılda yaşanan iki büyük dünya savaşı ve akabinde gelişen Soğuk Savaş dönemi bilimsel gelişmelerin hızının artmasına vesile olsa da bu gelişim her zaman olumlu sonuçları beraberinde getirmemiştir. Nitekim yaşanan nükleer felaketler, salgın hastalıklar, fabrikalardan sızan zehirli atıklar, kitle imha silahları içinde yaşadığımız dönemi belirsizliklere bırakmaktadır.

2019'un Aralık ayında Çin'de ortaya çıkan ve hızlı bir şekilde dünyaya yayılan Covid-19 salgını ekonomik, siyasi, sosyal tüm alanlarda kendini hissettirmektedir. Küreselleşmenin etkisiyle virüsün bulaşma çabukluğu birleştiğinde dünya genelinde 185 ülkede görülen küresel salgının etkileri de büyük olmuştur. Dünya ekonomilerinin tamamının olumsuz etkilendiği salgın nedeniyle tüm hayata ket vurulmuş, eğitimden spora, sanattan bilimsel toplantılara kadar birçok faaliyet durdurulmak zorunda kalmıştır. Dünyada daha önce de salgınlar olsa da bunlar belirli bölgelerle sınırlı kalmıştır. İlk defa küresel anlamda bütün ülkeler kendini tehdit altında hissetmektedir. Bu bağlamda salgının yayıldığı ilk dönemlerde büyük bir panik havası yaşanmış, sokağa çıkma yasakları ve karantina uygulamaları hükümetler tarafından uygulamaya konulmuştur. Ancak küresel kapitalist sistemin tüketime 
dayalı yapısı bu önlemlerin daha fazla sürdürülemeyeceğini göstermiştir. Buna bağlı olarak kontrollü sosyal hayat, maske, sosyal mesafe, hijyen, tedbir gibi kavramlar hayatımıza girmiş ve günlük yaşantının bir parçası olmuşlardır. Kitle iletişim araçları da bu dönemde salgınla ilgili alınan kararları, yaşanan gelişmeleri dünya kamuoyu ile paylaşmışlardır. Ancak bunu yaparken hangi kelimeleri tercih ettikleri, riske dikkat çekerken hangi sıklıkla sürece dâhil oldukları bu araştırmanın konusu olmuştur.

Bu çalışma da Türkiye'de faaliyet gösteren Sözcü ve Hürriyet gazetelerinin haber siteleri üzerinden nitel ve nicel içerik analizi tekniği uygulanarak bir araştırma gerçekleştirilmiştir. Araştırma kapsamında 2020 Mayıs ayı içerisinde her iki internet sitesinde Covid-19 anahtar kelimesiyle yapılan geriye yönelik taramada Hürriyet' in 2213 haberde, Sözcü'nün ise 2896 haberde salginla ilgili bilgilere yer verdiği elde edilmiştir. Elbette bu haberlerin tamaminın doğrudan salgınla ilgili olduğu söylenemez ancak corona, virüs, salgın, kovid gibi ifadeler kullanılmadan cümle kurmanın zor olduğu günümüzde ilgili haber siteleri de doğrudan veya dolaylı olarak haberlerinde bu ve benzeri sözcüklere yer vermişlerdir. Çalışma kapsamında ilgili haberlerin her iki sitede de mayıs ayı içerisinde dengeli bir şekilde paylaşıldığı tespit edilmiştir. Hürriyet haberlerini daha çok spor, dünya, ekonomi ve gündem kategorilerinde sunarken; Sözcü gündem, dünya, ekonomi kategorilerinde haberlerine daha fazla yer vermiştir. Hürriyet'in sitesinde yer alan haberlerin dörtte biri Covid-19 ifadesi geçmesine rağmen mevcut durumla ilgisizken Sözcü'de bu oran beşte bir seviyesindedir. Kullanılan haber kaynaklarına bakıldığında Hürriyet'in Sözcü'ye göre daha fazla haber ajanslarına başvurduğu söylenebilir. Hürriyet paylaştığı haberlerde daha çok Kovid ve Korona gibi Türkçe ifadeleri tercih ederken; Sözcü Corona ifadesini daha çok kullanmıştır. Vaka sayılarının açıklanmasına ilişkin yapılan istatiksel bilgilendirmeler adeta bir rutin haline gelmiş ve kitle iletişim araçlarının bu duruma özel sayfalar oluşturmasına neden olmuştur. Nitel ve nicel içerik analizinin karma bir biçimde kullanıldığı bu çalışmada Covid-19 Ulrich Beck' in Risk Toplumu bağlamında değerlendirilmiş ve ilgili haber sitelerinde bir aylık dönemdenasıl sunulduğu açıklanmaya çalışılmıştır. Bu bağlamda mevcut durumun uzun süre gündemi meşgul edeceği anlaşılmaktadır. Covid-19'un toplum üzerinde yarattığı etkiler sosyolojik ve derinlemesine araştırmalar yapılarak ortaya konabilir ve literatüre katkı sağlanabilir. 


\title{
EXTENDED ABSTRACT
}

\section{A Review Of Covid-19 News In The Context of the Risk Society}

\author{
* \\ Mahmut Akgül - Efe Numan Can
}

Today's society is full of risks. The September 11 attacks showed that not only countries and big companies but also ordinary citizens are the target of terrorism. However, we are faced with great risks every day such as global warming, AIDS, HIV, the danger of nuclear war, epidemics, and major accidents (Slatterry, 2014, p. 454). In this study, based on Ulrich Beck's work titled Risk Society, the presentation of the Covid-19 outbreak in internet news outlets will be examined with a mixed method. In this context, the expressions and preferred words used in the presentation of the Covid-19 outbreak on news sites are the main research question. The study is specific due to the fact that in addition to a large number of academic products written about the Risk Society, the news about the Covid-19 outbreak is examined on all the news published in the internet news organs within a period of 1 month. Considering the abundance of data used, it is thought to contribute to the literature.

The concept of risk is the danger or threat that awaits the person entering the activity as a result of an activity. It operates by knowing that this activity is a danger and may encounter a negative consequence. The concept of risk is a concept developed in sea trade against the dangers of looting by pirates(Ertürk, 2018, p. 281). According to Furedi (2001, p.43), the concept of risk refers to the possibility of experiencing adversities that may result in damage, damage, injury or death in case of danger. According to Beck (2014, p.24), the concept of risk was individual in the period when explorers like Christopher Columbus lived, and the term risk evokes courage and adventure, not threats affecting the whole human life.

Although technological development has many features that make human life easier, it also brings threats and dangers with it. As a matter of fact, two great world wars have led to mass deaths with technological development possibilities. Technological development has had a direct impact not only on the war industry but also in many other areas of life. Developments 
in the last century, especially in terms of mass media, have been one of the main factors in the transformation of societies. However, the effects of mass media can be divided into positive and negative effects, just like technological developments do in other fields. Mass media, whose main task is to inform and entertain, is effective in shaping attitudes and behaviors by manipulating the masses. At the beginning of the 20th century, the most important source of information was the newspaper; In the period following World War I, the radio has increased its influence. So much so that it is understood that the news given through the mass media has significant effects on the masses.

The Covid-19 epidemic coincides with the present day, when there are no borders with the effect of globalization and travels and human circulation are taking place rapidly. Covid-19 spread all over the world in a short time due to human mobility, advanced vehicles used in travel technologies, etc., just like the speed of the circulation of information.

In this study, the presentation of news about the Covid-19 outbreak on internet news sites in the context of the risk society is examined. Mixed method was preferred in the study. In this context, content analysis, one of the quantitative and qualitative research methods, was used. Content analysis is defined as a technique that allows valid inferences from texts or other meaningful contents and evaluated in the context in which they are used (Krippendorff, 2004, p.18). According to Yıldırım and Şimşek (2008, p.227), in cases where the data are similar, it is to group them with certain themes and to transform them into a format that the reader can understand more easily.

In this study, a research was carried out on the websites of Hürriyet and Sözcü newspapers. Qualitative and quantitative content analysis was used in the context of this research. Within the scope of the research, it was found that Hürriyet included information about the epidemic in 2213 news and Sözcü in 2896 news in a retrospective search performed with the keyword Covid-19 on both websites in May 2020. Of course, it cannot be said that all of these news are directly related to the epidemic, but today, when it is difficult to make sentences without using expressions such as corona, virus, epidemic, covid, relevant news sites have included these and similar words in their news directly or indirectly. Within the scope of the study, it was determined that the relevant news were shared on both sites in a balanced manner in May. Hürriyet presents its news mostly in sports, world, economy and agenda categories; Sözcü gave more space to his news in the categories of 
agenda, world and economy. While one fourth of the news on Hürriyet's website is unrelated to the current situation despite the mention of Covid-19; In Sözcü, this ratio is around one fifth. Looking at the news sources used, it can be said that Hürriyet applied to news agencies more than Sözcü. While Hürriyet prefers Turkish expressions such as Kovid and Corona in the news it shares; Sözcü used the Corona expression more. Statistical information regarding the explanation of the number of cases has become a routine and caused the mass media to create special pages for this situation. In this study, in which qualitative and quantitative content analysis is used in a mixed manner, Covid-19 has been evaluated in the context of Ulrich Beck's Risk Society and it has been tried to explain how it is presented in the relevant news sites in a one-month period. In this context, it is understood that the current situation will occupy the agenda for a long time. The effects of Covid-19 on society can be revealed through sociological and in-depth research and contribution can be made to the literature.

\section{Kaynakça / References}

Acar, Y. (2020). Yeni Koronavirüs (Covid-19) salgını ve turizm faaliyetlerine etkisi. Güncel Turizm Araştırmalarn Dergisi, 7-21. https://doi.org/10.32572/gun$\underline{\operatorname{tad} .703410}$

Ahmad, T., Khan, M., Khan, F. M., ve Hui, J. (2020). Are we ready for the new fatal Coronavirus: Scenario of Pakistan? Human Vaccines $\mathcal{E}$ Immunotherapeutics, 736-738. https://doi.org/10.1080/21645515.2020.1724000

Aktan, S. (2020, 316). Tarihteki en ölümcül salgın hastalıklar neden ortaya çıktı ve nasıl sona erdiler? 24.4.2020 tarihinde https://tr.euronews.com/2020/02/16/tarihteki-enolumcul-salginlar-hangileriydi-neden-olustular-ve-nasil-sona-erdiler adresinden alınd 1

Aslan, A., (2020). Risk toplumu ve din: Yeni bir sosyolojiye doğru. Mukaddime. 11, 274279.

Ayittey, F. K., Ayittey, M. K., Chiwero, N. B., Kamasah, J. S., ve Dzuvor, C. (2020). Economic impacts of Wuhan 2019-nCoV on China and the world. Journal of Medical Virology, 473-475. https://doi.org/10.1002/jmv.25706

Bakır, H., ve Bahtiyar, G.(2013) Ekolojik modernleşmeye karşı risk toplumu. II. Türkiye Lisanüstü Çalışmaları Kongresi. Bursa: Bursa Büyükşehir Belediyesi Kitapliğ1, 1355-1366.

Bakir, V. (2010). Media and risk: old and new research directions. Journal of risk research, 13(1), 5-18. 
Bayhan, V. (2002). Risk toplumu. Doğu Batı Dergisi, 187-202.

Bayhan, V. (2011). Küreselleşme ve risk toplumu. Sosyologca Dergisi, 203-217.

Beck, U. (2005). Siyasallı̆̆ın icadı. (N. Ülner, Çev.) İstanbul: İletişim Yayınları.

Beck, U. (2014). Risk toplumu: Baka bir modernliğe doğru. (K. Özdoğan, ve B. Doğan, Çev.) İstanbul: İthaki Yayınları.

Bogoch, I. I., Watts, A., Thomas-Bachli, A., Huber, C., Kraemer, M. U. G., ve Khan, K. (2020). Potential for global spread of a novel coronavirus from China. Journal of travel medicine, 1-3.

Canpolat, N. (2012). Risk toplumunda halkla ilişkiler şirketlerinin kriz ve kriz iletişimine yönelik bakış açılarının değerlendirilmesine yönelik bir araştırma. Gümüşhane Üniversitesi İletişim Fakültesi Elektronik Dergisi, 1(3), 119-134.

Chen, S., Yang, J., Yang, W., Wang, C., ve Bärnighausen, T. (2020, 02 24). COVID-19 control in China during mass population movements at New Year. https:/www.thelancet.com/journals/lancet/article/PIIS0140-6736(20)304219/fulltext adresinden alınd

Chiodini, J. (2020). Maps, masks and media-Traveller and practitioner resources for 2019 novel coronavirus (2019-nCoV) acute respiratory virus. Travel Medicine and Infectious Disease. doi: 10.1016/j.tmaid.2020.101574

Cohen, M. J. (1997). Risk society and ecological modernisation alternative visions for post-industrial nations. Futures, 29(2), 105-119.

Columbus, C., Brust, K. B., ve Arroliga, A. C. (2020). 2019 novel coronavirus: an emerging global threat. Baylor University Medical Center Proceedings, 209-212. https://doi.org/10.1080/08998280.2020.1731272

Cottle, S. (1998). Ulrich Beck,risk society'and the media: A catastrophic view?. European journal of communication, 13(1), 5-32.

Çelik, F. (2020). İstanbul Büyükşehir Belediye Başkanlığı seçimi'nde adayların twitter içeriklerinin siyasal iletişim açısından incelenmesi. Erciyes İletişim Dergisi, 123-148. doi: http://10.17680/erciyesiletisim.605538

Çevik, M. O. (2014). Modern toplumun güvenlik çıkmazı: tehdit, risk ve risk toplumu perspektifinde güvenlik. Uluslararası Hukuk ve Politika, 37.

Dursun, Ç. (2010). Dünyada bilim iletişiminin gelişimi ve farklı yaklaşımlar: Toplum için bilimden toplumda bilime. Kurgu, 1-35.

Du, Z., Wang, L., Chauchemez, S., Xu, X., Wang, X., Cowling. BJ. ve Meyers, L.A. (2020). Risk for transportation of 2019 novel coronavirus disease from Wuhan to other cities in China. Emerg Infect Dis. 26 (5). May. https://doi.org/10.3201/eid2605.200146 
Elo, S., ve Kyngäs, H. (2008). The qualitative content analysis process. Journal of Advanced Nursing, 107-115. https://doi.org/10.1111/j.1365-2648.2007.04569.x

Erendor, M. E. (2016). Risk Toplumu ve refleksîf modernleşme çerçevesinde siber terörizm: Tanımlama ve tipoloji sorunu. Cyberpolitics Journal, 1, 120-139.

Ertürk, D. (2018). Risk toplumu: Belirsizlik, korku ve güven arayışı arasında özne. Electronic Turkish Studies, 275-289. Doi: http://dx.doi.org/10.7827/TurkishStudies.13105

Esgin, A. (2013). İmal edilmiş belirsizlikler çağının sosyolojik yönelimi: Ulrich Beck ve Anthony Giddens Kaynaklı" risk toplumu" tartışmaları. Gaziantep University Journal of Social Sciences, 12(3).

Fitzgerald, S. T., ve Rubin, B. A. (2010). Risk society, media, and power: The case of nanotechnology. Sociological Spectrum, 30(4), 367-402.

Furedi, F. (2001). Korku kültürü. İstanbul: Ayrıntı Yayınları.

Giddens, A. (2000). Elimizden kaçıp giden Dünya. (O. Akınhay, Çev.) İstanbul: Alfa Yayınları.

Giddens, A. (2010). Modernite ve bireysel kimlik: Geç modern çă̆da benlik ve toplum. (Ü. Tatlıcan, Çev.) İstanbul: Say Yayınları.

Günerigök, M. (2017). Dünya risk toplumunda dinsel çoğulculuğu yeniden düşünmek. Mediterranean International Conference on Social Sciences by UDG içinde (s.548-557).

Güngör, N. (2018). İetişim. Kuramlar Yaklaşımlar içinde, Ankara: Siyasal Yayınevi.

Howell, J. P. (2012). Risk society without reflexive modernization? The case from northwestern Michigan. Technology in Society, 34(3), 185-195.

Kitzinger, J. (1999). Researching risk and the media. Health, risk E society, 1(1), 55-69.

Kleppe, B. (2017). Theatres as risk societies: Performing artists balancing between artistic and economic risk. Poetics, 64, 53-62.

Kline, S., Stewart, K., ve Murphy, D. (2006). Media literacy in the risk society: Toward a risk reduction strategy. Canadian Journal of Education/Revue canadienne de l'éducation, 131-153.

Krippendorff, K. H. (2004). Content analysis: An introduction to its methodology. California: Sage Pub.

Koçak, H., ve Memiş, K. (2017). Ulrich Beck'in Risk toplum teorisi bağlamında güvenlik ve özgürlük ikilemi. Afyon Kocatepe University Journal of Social Sciences, 19(2).

Korkmaz, A. (2019). Risk toplumu ve korku kültüründeki ebeveyn tutumlar ve genç gönüllülü̈̆̈̈̈. Yayımlanmamış Yüksek Lisans Tezi, Balıkesir Üniversitesi Sosyal Bilimler Enstitüsü 
Köse, H. (2007). Yeni risk tanimlamalari bağlaminda küresel medya. Selçuk İletişim Dergisi, 5(1), 42-51.

Lu, C., ve Zhang, Y. (2010). Reformation of voluntary food recall system from the angle of the theory of risk society. Agriculture and Agricultural Science Procedia, 1, 296-300.

Mahase, E. (2020, 05 10). Coronavirus: global stocks of protective gear aredepleted, with demand at "100 times" normal level: WHO warns. BMJ , 368-543 doi: 10.1136/bmj.m543 (Published 10 February: https://www.bmj.com/content/bmj/368/bmj.m543.full.pdf adresinden alınd1

Özben, M. (2010). Risk toplumunda nostaljinin kaçınılmazlığı: Güvenli bir yaşam arayış1 ve nostalji. Muhafazakar Düşünce Dergisi, 15-26.

Quilty, B. J., Clifford, S., group, C. n., Flasche, S., ve Eggo, R. M. (2020). Effectiveness of airport screening at detecting travellers infected with novel coronavirus (2019-nCoV). Eurosurveillance.

Rodriguez-Morales, AJ., Gallego, V., Escalera-Antezana, JP., Mendez, CA., Zambrano, LI., Franco-Paredes, C., Suárez, JA., Rodriguez-Enciso, HD., Balbin-Ramon, GJ., Savio- Larriera, E., Risquez, A., ve Cimerman, S. (2020). COVID19 in Latin America: The implications of the first confirmed case in Brazil. Travel Med Infect Dis. 2020 Feb 29:101613. Doi: 10.1016/j.tmaid.2020.101613

Saf, H. H. (2017). Risk toplumunda toplumsal denetim: WhatsApp darbesine facetime önlemi. TRT Akademi, 2(3), 160-180.

Slatterry, M. (2014). Sosyolojide temel fikirler. (Ü. Tatlıcan, ve G. Demiriz, Çev.) İstanbul: Sentez Yayınları.

Soydemir, S. (2011). Modernizmin karanlik yüzü: Risk toplumu. Sosyal ve Beşeri Bilimler Dergisi, 3(2), 169-178.

Timur, K. (2017). Ulrich Beck: Risk toplumu - başka bir modernliğe doğru. Intermedia International Peer-Reviewed E-Journal Of Communication Sciences, 188-192. Doi: 10.21645/intermedia.2017.31

Webster, A. (1999). Technologies in transition, policies in transition: foresight in the risk society. Technovation, 19(6-7), 413-421.

WHO Global Research on Coronavirus Disease (2020). Novel Coronavirus 2019: Global research on novel Coronavirus 2019. 12.06.2020 tarihinde https://www.who.int/emergencies/diseases/novel-coronavirus-2019/globalresearch-on-novel-coronavirus-2019-ncov adresinden erişilmiştir.

Wilson, M. E., ve Chen, L. H. (2020). Travellers give wings to novel coronavirus (2019nCoV). Journal of Travel Medicine, 1-3. https://doi.org/10.1093/jtm/taaa015 
Üvez, F. (2014). Medya ve risk toplumu ilişkisi bağlamında terör haberlerinin analizi. Yayımlanmamış Yüksek Lisans Tezi, Atatürk Üniversitesi Sosyal Bilimler Enstitüsü, Erzurum.

Yalçınkaya, T., ve Özsoy, E. (2003). Risk toplumu: Bilgi Toplumunun evriminde yeni boyut. II. Uluslararası Bilgi, Ekonomi ve Yönetim Kongresi (s. 1-10). Kocaeli: Kocaeli Üniversitesi Ï̈BF.

Yıldırım, A., ve Şimşek, H. (2008). Sosyal bilimlerde nitel arastırma yöntemleri. Ankara: Seçkin Yayıncilik.

Yıldırım, E. (2000). Küreselleşme, refah devleti ve risk toplumu. İstanbul: Alfa Yayınları.

Yıldırım, E. (2008). Risk toplumunda (depremle) yaşamak. Akademik Incelemeler Dergisi (AID), 3(1), 75-85.

YÖK. (2020, 05 10). COVID-19 yükseköğretim yol haritası. 10.05.2020 tarihinde https://covid19.yok.gov.tr/Documents/AnaSayfa/covid-19-yuksekogretim-yol-haritasi.pdf adresinden alınd 1

Corona Haberleri. (t.y). Sözcü Gazetesi. https://www.sozcu.com.tr/haberleri/corona/ adresinden erişilmiştir.

Corona Haberleri. (t.y). Hürriyet Gazetesi. https://www.hurriyet.com.tr/arama/\#/?page=1\&key=kovid\&order=Yeniden\%20Eskiye\&where=/\&how=Article,Column,NewsPhotoGallery,NewsVideo,Recipe\&firstPage=firstPage\&and=kovid\&startDate=31/12/2019\&finishDate $=31 / 05 / 2020 \&$ platform $=/ \&$ isDetail=true adresinden erişilmiştir.

\section{Kaynakça Bilgisi / Citation Information}

Akgül, M. ve Can, E, N. (2021). Risk Toplumu bağlamında covid-19 haberlerine yönelik bir inceleme. OPUS-Uluslararası Toplum Araştırmalarn Dergisi, 17(33), 535-564. DOI: 10.26466/opus.790554 